\title{
Democracy on the Five Star Movement's Rousseau platform
}

\section{Caroline Stockman \& Vincenzo Scalia}

To cite this article: Caroline Stockman \& Vincenzo Scalia (2020) Democracy on the Five Star Movement's Rousseau platform, European Politics and Society, 21:5, 603-617, DOI: 10.1080/23745118.2019.1705564

To link to this article: https://doi.org/10.1080/23745118.2019.1705564

册 Published online: 27 Dec 2019.

Submit your article to this journal $\pi$

Llll Article views: 96

Q View related articles ๘

View Crossmark data \lceil

4 Citing articles: 2 View citing articles 


\title{
Democracy on the Five Star Movement's Rousseau platform
}

\author{
Caroline Stockman and Vincenzo Scalia
}

University of Winchester, Winchester, UK

\begin{abstract}
The Five Star Movement, or M5S, is a popular anti-establishment, populist political party in Italy. One of its key features is the Rousseau platform, an online space designed to enable direct democracy. Named after the eighteenth century thinker JeanJacques Rousseau, it banks on the idea that the traditional state is corrupt, while the people's will can be more directly polled and executed as a governing force. However, Rousseau has also been critiqued for defending despotism and characterised as the enemy of liberty. This paper takes a closer look at Rousseau's 'Emile' and 'The Social Contract', and points out how a critical reading could raise questions about the platform's true meaning. The analysis focuses specifically on the illusion of autonomous choice and covert authoritarianism. The platform becomes a powerful tool of both preventive as well as repressive social control. As an anti-modern public sphere, it holds inherent threats to democracy itself.
\end{abstract}

\section{KEYWORDS}

Five Star; M5S; Rousseau; democracy; utopia; dystopia

\section{Introduction}

The Five Star Movement was formed in 2009, as an anti-establishment, populist political party in Italy. Its rapid growth both in presence as well as popularity has taken Italian politics somewhat by surprise and attracted further international attention. After winning the general election in March 2018 with 32 per cent of the vote (Bartlett, 2018a), it became the largest single party in Italy, and it is currently the most represented in Parliament. A key tool in its success has been the use of participatory online media: political blogging, meetup forums, online polling and surveys and fundraising. Each have played a role in civic aggregation and mobilisation, both online and offline, further driven by the combination of left-wing ideology and the professionally entertaining, charismatic rhetoric of its leaders. This formula has made it a unique party in its own right, even an anomaly in Western European politics (Turner, 2013). It has a strong oppositional voice to the rightwing alliance government in Italy, who collectively secured more seats and ruled Italy until August 2019.

Until the March 2018 elections, the party was formally led by Beppe Grillo, well-known Italian comedian. Initially, Grillo did not appear to be a proponent of a digital world, demonstrated by his live destruction of a computer on one of his shows in the 1990s (Turner, 2013, p. 180). However, with the help of Gianroberto Casaleggio, he came to 
harness the powers of mass online media in the years preceding the formation of the party. Gianroberto passed away in 2016, but his son, Davide Casaleggio, has taken up the legacy of Italian entrepreneurship and political activism. Due to the key importance of the platform, he is assumed to be one of the leaders of the Five Star Movement without holding a formal position. His importance lies within the movement's defining approach in its use of the internet, not only in the run-up to the formation of the political party, but in continued fostering and building its network of democratic hope. In its vision of internet-based politics, it aims to provide a moral offset to what is proclaimed to be the corrupt, closed, elitist Italian government. Casaleggio (2018, p. 39) writes that 'Our experience is proof of how the Internet has made the established parties, and the previous organisational model of democratic politics more generally, obsolete and uneconomic'. Instead, it presents itself as truly transparent and egalitarian, not orchestrated 'inside smoke-filled room like the established parties' (Casaleggio, 2018, p. 40). To this aim, Casaleggio has developed a new online platform for the movement, which enables 'direct democracy' otherwise unattainable. This platform was launched in 2016. Its functionality is explained in more detail below, but a key part of its possibility is that party members can draft their own bill proposals and put them up for vote. The threshold of public access is low, allowing eligible voters to engage with decision-making directly. This follows the utopian ideals of direct democracy (Castells, 2012/2015; Bartlett, 2018), where a country's actions are directly steered by its people, without potentially corrupted political processes.

In the first instance, this paper discusses the ideals of the Rousseau platform as proclaimed by the Five Star Movement. It is well aligned with utopian technological determinism, as demonstrated in Castells' theory on networked social movement - yet it is also crucially different in some respects. However, utopian societies are often marked by a darker side which either underpins or precedes its ideals. The key tool within the movement is the Rousseau platform, as the intended digital materialisation of direct democracy. It is named after the eighteenth-century philosopher, Jean-Jacques Rousseau, known to be a proponent of those ideals. Yet his writings are amongst the most contested, and often misunderstood, in theory and philosophy. It could therefore strike the critical observer as odd, that a political party which positions itself as morally superior, would choose to internalise the name of a theorist which has been named 'the most sinister and most formidable enemy of liberty in the whole history of modern thought' by Isaiah Berlin (2002, p. 49). This article will in particular focus on The Social Contract and Emile to have a closer look at some of the theoretical misgivings. The Social Contract was published in 1762 and key to his present-day reputation as a political theorist. In the same year, Rousseau also published Emile, or on Education which for its title is often read as a pedagogical treatise, but it is equally revealing to Rousseau's thought on society, socialisation and authority. The analysis presented here raises concerns on the use of Rousseau's name for a political utopia, as presented by the Five Star Movement, which resonates well with the known critiques on this party. This leads to the final section of this paper, which discusses the inherent threat of the Rousseau platform to modern democracy itself, using the public sphere and social control as key points of analysis. It draws attention to the need to perceive the platform as a tool within a particular socio-political context; a constructivist stance, against the claim of technological determinism. 


\section{Part 1: The utopian promise}

As society grows, face-to-face, local and direct democracy has historically transformed itself into representative democracy. With that has come a distancing of immediate government politics from its people. As the process of proposing, debating and deciding on policy has become more top level, concerns around corruption, elitism, personal agendas and behind-the-door deals have also emerged (Bartlett, 2018). The Five Star Movement has positioned itself directly against this, by casting the existing government in Italy as villainous, while occupying the moral high ground as a direct politics, one with the people, participatory and transparent (Casaleggio, 2018).

Digital technology, and in particular mass online media, has materialised the utopian promise within this political strategy. 'Using the internet, we changed the rules', according to Casaleggio (2017, p. 14). He is currently chairman of the association, co-founded by his father, which has developed and runs the Rousseau platform. This online space allows for members to comment on new bill proposals, vote on the ones to take to Parliament, share educational information on legislation and policy, make donations ... The importance of this and other online media tools are key to the party's political success, as Casaleggio (2017, p. 14) states himself: 'This was possible only through the extended use of the internet, which is the real game changer, a true revolution'. As Natale and Ballatore (2014) point out, the narrative typically used by the Five Star Movement is solidly aligned with digital utopianism: a deterministic belief in the power of technology to make a direct, positive change.

The Five Star Movement's narrative is much in line with a utopian, deterministic view on the internet as theorised by Manuel Castells. In his well-known book, Networks of Outrage and Hope (2012/2015), he describes the ubiquitous crisis of political legitimacy. Yet on the scene characterised by thousands of individual voices (of outrage), emerges the internet as a new space of autonomy (enabling hope). This space appears to be beyond the traditional monopolies of power, such as the ruling government and capitalist corporations. (At least, such is its utopian promise.) Online, people find each other naturally and create networks, which allow individuals to unite, share their purpose and message, and overcome fears of oppression. Castells (2012/2015) observes such networked social movement occurring globally, relying on the internet and fostering relations in local gatherings, to drive policy and make a positive, direct impact on society. To him, the internet 'embodies the culture of freedom' (Castells, 2012/2015, p. 231). He theorises that there is 'a virtuous circle between the technologies of freedom and the struggle to free minds from the frame of domination' (Castells, 2012/2015, p. 233).

The emancipatory potential of digital technology is well aligned with the progressive, oppositional political messages of the Five Star Movement. Casaleggio and Grillo (2011, p. 10) state that 'The citizens who find information online do not watch TV and do not read newspapers. They live in a parallel dimension. They are informed, the others are disinformed by Power' (in Natale \& Ballatore, 2014, p. 114). The general idea is that greater connectivity and easier, free access to information outside of government control and commercial news providers will create a more informed citizen for both online and offline society. In this sense, its commendable aim is 'Democracy. A new form of democracy. An old aspiration, never fulfilled, of humankind' (Castells, 2012/ 2015, p. 315). 
Perhaps the main feature of networked social movements according to Castells (2012/ 2015) is the spontaneous and natural gravitating of individuals to each other in the online space, forming togetherness based on their shared fears, dreams and hopes. According to Manuel Castells (2012/2015, p. 282), the Five Star Movement is not an autonomous networked social movement such as the one he observes in other countries. In his view, it is a populist movement, oppositional to the distrusted ruling government, indicative of the crisis of representative democracy. Though it is similar in its proclaimed digital utopianism, it falls short of being a networked social movement in various aspects, and its utopian promise, as discussed further in the next paragraph. Through a critical reconsideration of the party's key platform, and its namesake Jean-Jacques Rousseau, the analysis in the following paragraph brings out the questionable ironies in the platform's political narrative of direct democracy.

\section{Part 2: Rousseau's fallacies}

The Five Star Movement's narrative resonates well with Rousseau's Second Discourse, also titled Discourse on the Origins of Inequality among Men, published in 1754. In this text, the ruling government is presented as deceiving and manipulative, as it is the rich men of society who intend to suppress the poor by making them believe is in their best interest to comply with existing law and order. 'In the natural order, men are all equal', Rousseau states (1762/1979, p. 40), and some say that indeed, the internet 'creates the conditions for a form of shared practice that allows a leaderless movement to survive' (Castells, 2012/ 2015, pp. 229-231). So when Rousseau proposes each person is free and autonomous, he becomes 'a philosopher of hope, a prophet of action' (Kelly, 2006, p. 9). This appears to align well with the narrative of the Five Star Movement, positioning themselves from the start as an 'antipolitics' that casts all traditional political parties in a dim light as instruments of corruption (Agnew \& Shin, 2017, p. 929).

With that individual freedom to pursue innate instincts also comes social responsibility, in the form of civic duty to arrange order through politics, as described in The Social Contract. In that sense, he is as much a philosopher of despair in regard to the state of society. Though society was fundamentally considered corrupting to natural instincts, Rousseau did admire man's collective ability to create, demonstrated for example by his awe for civil engineering projects and communal achievement (Simon, 2012). It entailed a sense of accomplishment in advancing the human condition. The internet can be regarded in much the same way; as a collective effort, a progress for all, by its streams of information. To Rousseau, 'fatherland and citizens should be effaced from modern languages' (1762/ 1979:40). He disliked the 'citizen'; subjecting under the authority of an artificial social institution while natural man is one with the larger whole relative only to himself. Man/citizen presented an inherent duality for each person which they nonetheless had to occupy (Horkheimer, 1947). Nevertheless, Rousseau's ideas are widely acknowledged to be foundational to the French revolution, and thinkers such as Karl Marx - whose ideology at times does not appear far removed from the Five Star Movement's narrative. According to Davide Casaleggio (2017, p. 14), Rousseau's name was chosen for the platform as he believed that the only way to know what people want is to ask them.

In Rousseau's book Emile, or On Education, a fictitious orphan Emile is educated by 'Jean-Jacques', his tutor. The book provided a response to his earlier Discourse on 
Inequality. A key concern is the corruption of society which would irreversibly impact on the innate goodness of natural mankind, which is present in every person. Purposeful intervention is therefore needed, so Emile is removed from society at birth, in order to have a good, moral upbringing away from corrupting influence. It can be reconciled by the idea that conscience comes as an innate faculty, but that there is the possibility of learning to ignore the voice of conscience (Potts, 2015) - hence the foundational necessity to be taught to love virtue, free from corrupting influence. The ultimate goal is for Emile to become a member of society again, once he has been educated to be independent and critically minded. Often read as a pedagogical treaty, a common interpretation of this book is that it emphasises natural freedom and choice. However, like much of his writing, it is full of inherent paradox and discursive ambiguity (Szkudlarek, 2017, p. 27). For example, Rousseau questions whether any bad inclinations of the child are not the result of adult intervention. But at the same time, adult intervention is crucial to Emile's education. The adult decides what Emile should learn, how and where, even who to marry and what to find lovable about his partner. That happy ending in Emile has been called deceptive, odd and even deeply disturbing (Reisert, 2003, p. 167). Books are banned - apart from Robinson Crusoe. The regime of control and manipulation made Gray (2015, p. 23) conclude: 'Pity poor Émile!'

Rather than trusting the natural inclinations of the child, 'Rousseau's vision is one in which every decision of the child, and every lesson learned, is cleverly controlled by the brilliant master' (Gray, 2015, p. 24). Such single authoritative figures are not uncommon in Rousseau's writing; 'his demigods of authority redirect nature into new patterns of order' (Kelly, 2006, p. 36). A dominant reason for Emile's move to the countryside is that this social space is much more easily controlled by Jean-Jacques; he will be 'master of the objects he wants to present the child' (Rousseau, 1762/1979, p. 95). The environment is carefully and secretively curated by a single person: Emile's tutor, Jean-Jacques. Rousseau's idea of negative education works because he has consciously built the boundaries of another person's world. Freedom only exists within the delineated boundaries. This is the reason why Trifonas (2006, p. 25) deemed Rousseau's method to be deceptive. Freedom and independence is set up as an illusion, because 'he plays and explores with just those materials, and in just those ways, and thereby learns just those lessons, that the master has chosen for him' (Gray, 2015, p. 24). Here lies the difficulty with the Rousseau platform, and perhaps the reason why it is so far removed from a true networked social movement: the online space is not free and natural. It is a purposefully built, politically laden, curated platform, which is designed on proprietary software and controlled by one company who is closely allied with its client: a political party, who actively uses it for its own promotion and continuation.

The Rousseau platform incorporates an 'E-learning' section, where informative videos intend to function as a free peer training platform. This content aims to educate those less politically experienced in a variety of topics, from constitutional and legislative regulations, the role of committees and department, local administration, and so on. In this sense, the network of peers is empowering to individuals and the network. Individuals can overcome the powerlessness that stems from lack of knowledge and take purposeful action - which will strengthen the network's ultimate aims. Much like 'Emile must be taught to love virtue because he is not able on his own to discover the wisdom to govern his actions in accordance with reason' (Reisert, 2003, p. 145). However, the 
medium is the message too. Here, an apparent contradiction occurs between the utopian idea of the informed citizen versus the practicalities of politics through online media. Bartlett (2018a) succinctly points out why online media is favoured by populist politicians and their followers. First, the communication channels are made for the delivery of short, emotional, stirring messages. There is a receptive online audience, who readily engages with the brevity of the message rather than extensive, time-consuming research into complex policy. There is the perception of delivering 'the truth' straight to the people. It is simple and immediate, fast and personal (Bartlett, 2018a, p. 2). These are handy tools in political ambitions, but the quick, emotional consumption of information seems to be in contrast to the idea of the well-informed, self-educated citizen. It is not emotion as such which may cause the issue; as emotion is the precursor to communities and transformative action, according to Castells (2012/2015). Asserting freedom of mind through moral consideration takes time; yet the nature of online media seems to stimulate distraction and speed, unethical persuasion tactics, 'echo chamber' beliefs or misinformation (Bartlett, 2018b). All of these may form greater threats to true democratic ideals.

Rousseau's character Jean-Jacques, referred to by his fictitious orphan as 'the master', is 'an extraordinarily intelligent, accomplished, devoted man who continuously studies Émile, gets to know his every motive and whim, and uses that knowledge to provide the boy with just those experiences that best impart the exact lessons that the master deems appropriate' (Gray, 2015, p. 2). So at the heart of Rousseau's most well-known postulations of humankind appears to be a supreme leader, who maintains overt standards of trust and openness, but is actually controlling, deceptive and distrusting of both individual inclinations as well as the influence of society at large. 'Much as he hated inequality he did not want equality either, and positions of superior and inferior were to be maintained' (Shklar, 1964, p. 158). The figures of authority in his writing are pervasive and all-encompassing. They are admired even, as the character Emile expresses at the end of the book to his tutor Jean-Jacques: 'Advise us and govern us. We shall be docile. As long as I live, I shall need you' (Rousseau, 1762/1979, p. 480). The tension between individual freedom and imposed authority is not atypical for Rousseau's theories, which often shows his conviction that authority corrupts the natural inclinations which includes innate goodness, and yet his belief for a superior to be in place to enforce his rule (Kelly, 2006, p. 36). Turner (2013) analyses the Five Star Movement as 'deeply personalist', meaning the key figures of the party are much more controlling to the decision-making and the ideological drives than it perhaps proclaims - much like Rousseau's character Jean-Jacques. The genesis of the party in Grillo's top-down monopoly of one of the movement's key online media, the blog, is an indicator of this. Also, the Casaleggio influence (both father and son) has been considered a grey eminence in the party. In February 2018, Davide Casaleggio was described by the New York Times as 'the mystery man who runs Italy's 'Five Star' from the shadows' (perhaps much like Jean-Jacques intends to be to his tutee Emile). This uncertain, unofficial capacity seems to be in contrast to the claims of transparency, and the overt aim to establish a leaderless democratic movement. In 2018, the party also overtly became somewhat less leaderless, as Luigi Di Magio took up the role of official party leader. Wired Magazine has noted that this election had 'a somewhat cosmetic appearance of choice', with Casaleggio himself declining to speak with them. 
Deseriis (2016a) lists other critiques on the Rousseau platform, such as the technicality that the platform does not technically verify the vote, which opens up allegations of untrustworthiness. He also questions the running of the platform on a proprietary source code, which doesn't seem well aligned with values of transparency and openness. Other critiques relate to wider societal concerns of data privacy, both in protecting personal information from security threats, as well as intentional use of private data and voting records (Federici, Braccini, \& Saebø, 2015, p. 292). Perhaps the most incriminating are allegations from former party members that votes are being manipulated (Horowitz, 2018). What is meant there are purposeful, hidden interventions to skew the open process of decision making, much like Jean-Jacques did for Emile. There are open elements to process, as designed into the Rousseau platform, which don't quite meet the target of true direct democracy. For example, in the 'Lex Members' section of the Rousseau platform, the party members can draft and put bills up for vote. However, they are screened by an internal team, which will not allow unconstitutional votes to be published, or those that belong to different legislative bodies (Deseriis, 2016a). This seems reasonable enough, though it remains a background process. Then, each eligible member can cast five preferences across the approved proposals. Deseriis (2016a) counted 129 proposals to choose from, which are arranged on the webpage without taxonomy based such as categories related to the topic of interest, for example. This may be aligned with the party's general view that traditional hierarchical structures of society or intermediaries to decision making should disappear (Casaleggio \& Grillo, 2011, p. 10). Interestingly, in The Social Contract, Rousseau did not advocate majority votes, instant democracy or the idea that individuals get to vote on particulars of legislation. His second chapter describes that the general will can only comment on general matters, and in doing so, materialise a desire for a common good: 'the factor which makes the will general is not so much the number of persons voting, but rather the common interest that unites them' (Rousseau, $1762 / 1994$, p. 69). The tension between the general will and individual self-interest is present throughout his writing. Though The Social Contract warns against this, it does not provide great practical insight into how to avoid it. In any case, the Five Star Movement's slogan 'Participate, don't delegate!' is not what Rousseau wrote. The sovereignty of the people remains a steering force, but the government still manages executive decisions on its affairs, and considerable delegated power was assigned to the oft-critiqued figure of 'the legislator'. Rousseau is therefore not a proponent of direct democracy. In fact, he has been criticised for providing the philosophical tools for modern tyranny and despotism (Berlin, 2002) though Williams (2005) and others have mediated this in less extreme terms.

Information overload appears to be another emerging problem for the platform (Federici et al., 2015, p. 294), already a well-known issue of the internet at large. As Deseriis (2016a) points out, the resulting votes may simply go to those proposals at the top of the list, rather than the ones further down. Decision making is apparently fast: members are not pre-notified of a vote opening and should cast their votes quickly. Whereas Rousseau wrote: 'I should warn my readers that this chapter must be read without haste, and that I am ignorant of the art of making myself clear to those who do not wish to concentrate' (Rousseau, 1762/1994, p. 91). The proposals however are already available in advance and open to comment. But as Deseriis (2016a) notes, the lack of an anticipated time to vote is likely to reduce interaction with the material. After the voting window, 
the two most popular proposals will be brought to Parliament by the proposing member and an assigned tutor who will aid the process. They should take into account the most significant comments made online by the voting members and amend the bill accordingly before Parliament. This curation appears to be again more personalist rather than a shared effort. To some extent, these features of the Rousseau platform may arise from practical needs, but more cynical interpretations are equally possible - particularly when revisiting's Rousseau's views on authority. For these and other reasons, the platform has been called 'an empty shell' and even 'a hoax' by a former M5S party member (Trinchi, 2019).

Perhaps a final concern in view of the utopian use of the internet which Castells envisions, and not a trivial one, is that the Rousseau platform does not appear to enable much direct communication between members of the network in an autonomous, free and open way, 'free from the control of those holding institutional power' (Castells, 2012/2015, p. 10). Such horizontal communication is key to the drive of social movement: 'the more interactive and self-configurable communication is, the less hierarchical is the organisation and the more participatory is the movement' (Castells, 2012/2015, p. 15).

\section{Part 3: The threat to democracy}

The previous paragraph has critically reviewed the meaning of the Rousseau platform in view of its namesake, the eighteenth-century theorist. While it is a retrospective analysis, the conscious act of naming the platform merits such critical investigation. Especially as it leads to deep concerns about its features which may undermine the touchstones of contemporary democracy. In particular, we discuss the potential of the platform as a powerful tool of social control and surveillance, after a consideration for the public sphere in modern politics.

Jurgen Habermas (1962/1974) envisages public sphere as an intermediate layer between private and public, where society, politics, culture and economics meet. The roots of modernity lay in the birth and development of public sphere, which articulates on individuals and social groups expressing specific interests and values to be either defended or promoted in the political arena. The outcome of a public sphere is a reinforcement of democracy, as the intertwining of a web of plural goals, aims and cultures promotes the implementation of civil liberties, both by limiting the authoritarian action of governments and by taking on stage new subjectivities. For this reason, Habermas has constantly argued the need for a 'communicative reason' (1962/1974) to counterbalance an 'instrumental reason' which characterises the action of governments, both under the authoritarian aspect and under the performative one. In other words, politics cannot be reduced only to the allocation of resources, neither can it be left to the free and unlimited decision of the sovereign, as its consequence would be a politics devoid of contents, wherein the power to decide would be overemphasised, and the 'state of exception' would be the way out for politics to gain legitimacy (Agamben, 2003).

The Rousseau platform is by this token an 'anti-modern' public sphere. First, because it works through a top-to-bottom pattern: it is not individuals, interest groups, classes, cultures challenging the sovereign with new and plural demands, but, rather, the other way around. Deseriis (2017) describes the actuality of the party as a leaderist-cybercratic variant of technopopulism, in contrast to truly open, decentralised and participatory networked activism. This was also one of the main concerns Castells (2012/2015) identified against 
characterizing the Five Star Movement as a true form of social democracy. The sovereign proposes to individual citizens its singular issues around which they have to make a twotier choice, without any possibility of mediation. Unlike Rousseau himself, the Rousseau platform does not recognise the existence of pluralism, and it oversees the possibility that society can be organised and express by this token its own subjectivities. In contemporary global society, with pluralism, multiculturalism, diversity becoming more and more an issue at stake, the organisation of public spheres from above by proposing a limited amount of issues becomes a real threat both to democracy and to civil liberties. Deseriis (2016b) concluded that there is a clear filtering process in place, protecting the autonomy of elected representatives, and some of its structural intent actually undermines the ability of direct democracy to function adequately. To some extent, this is worse than overtly authoritarian governments. Bringing a society to believe it has individual power, while blinding to the true situation of oppression, takes active yet veiled manipulation. Alongside this, Rousseau described clearly in The Social Contract that the people's will should only concern general matters, not particular legislation.

Second, the Rousseau platform is not a public domain, but, rather, a private platform. Bartlett (2018b, p. 138) points out that tech giants have 'stayed out of the messy business of politics for many years, but as they've grown, so have their opportunities for influence'. The social chamber of policy makers and technocrats has grown smaller, so shared views and assumptions work together in two powerful spheres of society. Castells (2012/2015, p. 8) discusses how networks of power in various domains of human activity can come together in partnership around specific projects. The common interest is the goal to control the capacity of defining the rules and norms of society. Italy has been dominated for 20 years by the TV tycoon Silvio Berlusconi, who was also the owner of private TVs and newspapers, thus arising the problem of the interest conflict between private and public interest. Agnew and Shin (2017) demonstrate how Berlusconi was in that sense not atypical, as populist movements often seem to need a focal point in a leader who dominates the audience's attention. The Rousseau platform poses an even worse problem in relation to conflict of interest. The Casaleggio Associati firm has indeed proposed the Italian public a format, with MPs accurately selected, signed and obliged to subscribe their total acceptance of the screenplay which was drafted by the experts of the company. In other words, a crucial political form of contemporary society, such as that of democracy, is being used for the purpose of profit by a private actor. This aspect also marches in the opposite direction of public sphere as envisaged by Habermas. Private entrepreneurs have played a capital role in shaping modern politics, as their quest for freedom of enterprise has massively contributed both to overthrow the absolutist regimes and to claim the importance of individual liberties. A leading principle of political liberalism, and of Rousseau's Social Contract has been, since the outset that individual interests coincide with collective interest. It was because of this assumption that the bourgeoisie grew to be the 'general class', leading society to progress and prosperity. In the case of the Rousseau platform, we are facing the opposite trend: public interests such as those of civil liberties, democratic participation, pluralism are being used for the pursuit of a private interest, impoverishing a democratic debate that has already suffered the blows of neo-liberalism. As a consequence of this, the Rousseau platform marches hand in glove with the rising populist wave in Europe. An impoverished public sphere, wherein private and privatised actors operate (Bauman, 2003), gathers around slogans, passwords, campaigns fuelled from 
above by an unaccountable informatics platform, making room for resentment feelings built around a scapegoat. Hill (2017) points out a twenty-first century trend to turn democracy into politicised entertainment, favoured by speedy, unbuffered decision making. He positions this as a form of tyranny, against liberal democracy.

The aspect of unaccountability is the third and relevant aspect of the Rousseau platform. The public sphere has managed, since its inception, to limit the power of the sovereign by setting up specific rules and procedures which are agreed upon the vast majority of society. This aspect has made it possible the development of collective participation, because the limitation of power, as well as its being accountable to the public, has allowed the possibility to develop a public awareness such matters as power abuses and other misdemeanours committed by the sovereign. The Rousseau platform, on the contrary, is totally unaccountable: its organisers are unknown, and cannot be questioned about their deeds because they are private, not public subject, free to develop their strategies of manipulation and control over society. According to The Financial Times, their funding stream is opaque, but appears derived mostly from donations, the MP membership fees, and from online advertising revenue (Politi, 2017). In the meantime, Five Star supporters chanted one of the party's slogans, 'Honesty!', at Gianroberto Casaleggio's funeral (Loucaides, 2019). Bartlett (2018b, p. 7) describes that the looming dystopia to fear is a shell democracy run by smart machines and a new elite of 'progressive' but authoritarian technocrats'. His concern is not that democracy would disappear; but that it would become a hollow word, an illusion of empowerment and influence while real decision-making is steered by an elitist group.

This poses the problems related to social control. These are the ways society addresses all the individuals and social groups who are deemed as 'deviants' by mainstream public opinion (Cohen, 1985). Social control practices have usually been developed from the top to the bottom. Magistrates, social workers, psychologists, police forces, throughout modernity, have been part of this network. They have worked in such a way as to either prevent the plurality of lifestyles and to repress any attempt to change social relations in deep (Foucault, 1976). Their work has not always been successful as social changes have occurred despite any attempt to either relent or to choke them down. In other words, imaginary, representations, perceptions and opinion of the greater majority of society have been brought to a uniform pattern by the media (Melossi, 2003). Newspaper, television, cinema, radio have become a powerful tool to mould public opinion in such a way as to discourage an embitterment of social and cultural conflicts. This process of uniformisation can be defined as a form of preventive social control, insofar as mass media convey to public opinion some specific models of behaviours, expectations and values which reduce the possibilities for different perspectives to be created. Since mass media are intertwined with unequal distribution of resources, as well as with the creation and development of a market of communications. Post-industrial society has been relying on the economy of knowledge which has replaced the old manufacture-based economy (Negri \& Hardt, 2000), conveying virtual commodities to the public. The Rousseau platform can be enshrined in these recent economic developments, as it is both structured and organised from above. It has though an innovative peculiarity, as it produces, sells and distributes political participation, thus emptying the public sphere. Activists, militants, common citizens don't gather spontaneously, don't discuss overtly their different their ideas, don't produce sense (Weber, 1971), that is they don't conjure up to elaborate an independent 
proposal. Interestingly, various analyses have pointed out a decline of online participation in the average number of Rousseau platform voters. Tentatively, Deseriis (2018) offers as a first explanation that the decision-making is too frequently solicited, and therefore onerous to the voters. Second, the lack of collaborative method which was inherent to the design of the platform. This absence of peer motivators discourages participation. However, its membership roll (of both certified and pending platform subscribers) exceeds the registration numbers of any other political party in Italy (Federici et al., 2015 , p. 288). The topics of discussion, the possible answers and the policies to either propose or to enact are decided beforehand by the Casaleggio Associati. As its CEO, Davide Casaleggio is 'the absolute ruler of Five Star's data' (Loucaides, 2019).

This is the same case as activists and militants, who are accurately chosen by a casting staff who skims away from the Five Star movement all those militants who don't fit into the framework. We can define this as preventive social control, as it works in such a way as to prevent deviant behaviour. There is also a form of repressive social control, as the Casaleggio Associati requires all those to participate to the activities to subscribe a contract in which they declare to accept the rules, as well as to abide by them. A violation of the rules, which is usually detected by a whistle-blower appointed by the firm, results into the immediate expulsion of dissident and violators. All the disciplinary procedures against the dissident members are not discussed and decided by appointed boards, neither do they follow specific procedures, and the accused militants are not entitled to defend themselves. We are by this token facing a sort of pre-modern form of social control, based on the fidelity of the member of a group rather than on their free will. This punishment-oriented approach can be surely qualified as anti-liberal, as it goes against both the presumption of innocence and the right of individuals to lead their own lives once they have spent their conviction. It certainly circulates a repressive and law-and-order attitude which encourages marginalisation. The Rousseau platform is the core of this authoritarian, anti-modern, control-oriented project.

David Lyon $(2007,2015,2018)$ has explained of late how surveillance has moved to a more dynamic, relational approach. The old 'vertical' systems, based on the repressive apparatus of the State, have been replaced by software deputised to control the pervasive technological contemporary communication systems. Aldous Huxley, in the dystopian prophecy during a 1958 interview with Mike Wallace, warned against the future tyranny of surveillance which would be covert, embedded, yet omnipresent. By using one's own metadata on the web, such as credit card numbers, residence addresses, driving licenses, it is possible for the controllers (governmental agencies, cool hunters, private corporations), to acquire as much information as necessary to know about the person or the groups of persons one wants to control. The same result is given by the control of social networks, as well as of the other web activities of the controllers. So on the Rousseau platform, the interaction of the public over issues such as economy, politics, crime, climate change, and more, are monitored to shape up a political proposal which fits into the supposed orientations of the audience they want to capture. This is fundamentally opposed to the more positive interpretation of Jean-Jacques Rousseau's intention. Kelly (2018) suggests that Rousseau called for citizens to 'have not only the right but the duty to hold the government accountable for its misapplications of the laws' (p. 16) and that 'the violation or misapplication of fundamental laws by the government is usually a more urgent problem than the existence of unjust laws' (p. 30). 
A political proposal which is not transparently filtered by any democratic procedure is potentially harmful for the destiny of democracies. Once the items are selected on the Rousseau platform, a selected public is invited to express its opinion about them. The outcome of the answer is not controlled by any external auditor, and the outcomes rarely require space for intermediate discussion, as they end up with a landslide positive or negative answer. That was the case of the decision to form a coalition government with the Northern League in 2018 with an overwhelming positive answer, whereas almost all the participants to the vote decided the party should have opposed the request of judges to put Salvini on trial for denying the ship 'Diciotti', carrying refugees, the access to the harbour of Catania in June 2018.

As controversial as a plebiscitary outcome can be, its effects are problematic for public opinion. First, it has the effect of deciding the policies which the current biggest Italian party must carry out. Moreover, the outcome is circulated by the Casaleggio Associati within the web as 'the people's will', which is inaccurate, as Agnew and Shin (2017) pointed out: internet voting does not remain unaffected by the geographical reality of the voters, non-voters and politicians. They concluded that 'the people is an eighteenth-century ideal that probably makes little sense today as a stand-in for a national population' (p. 930). Nevertheless, it might orient the opinion of hundreds of thousands undecided citizens and voters over matters which are crucial for Italy. The platform could equally push to reinstate death penalty, as the Five Star Movement has a very strong punitivist stance, and has built a good deal of its political fortune on anti-corruption campaigns which focused on embittering penal measures both for corrupt politicians and for street criminals. In any case, the Rousseau platform has set a standard, and other political forces, in the short term, could adopt a similar tool. Such platforms can become a powerful tool of social control, both in their preventive aspects, when it is an active tool to produce an authoritarian public opinion, and under their repressive use, when it can be an active tool of stigmatizing and marginalizing. The analysis presented here does highlight the need to re-emphasise the non-deterministic view on technology. The Rousseau platform may be designed, and perceived, as a utopian tool for direct democracy; yet simultaneously, it may be driven by a more centralist agenda, willingly or not leading to a blinding political culture. Its context of use, the various people and actants within the network of use, co-create its meaning to society. As always, it is important to look beyond the tool. (See for example the work of Marco Deseriis, on the embedding of political values and participatory democracy in the design of digital decision-making platforms.) Considering the concepts of public spheres, modernism and social control, the platform does have inherent threats to the ideals of democracy it proclaims to embody.

\section{Conclusion}

The Five Star movement is positioning itself as the morally superior choice in Italian politics and explicitly aims to be the nation's sole governing force. Its narrative centres on the materialisation of real democracy, one that is direct and unmediated. One of its key tools for this utopian promise is the Rousseau platform, which allows online voting amongst other direct democracy functionalities. It is named after the well-known Western theorist Jean-Jacques Rousseau, who proposed the general foundation to 
which the Five Star movement subscribes, centring on the people's will, against the corruption of the established government. The party's programme is based on the disaffection for politics by the Italian voters and their resentment over corruption.

So Rousseau's thinking appears to be a commendable framework of democratic politics, but he has been a controversial thinker for many reasons. Some have called him a proponent of tyranny and despotism. This paper has revisited some of Rousseau's propositions, particularly through The Social Contract and Emile. While the analysis is in that sense retrospective to a present-day interpretation of the Rousseau platform, this conscious name designation of a political party's central toolkit does merit such critical review. In contrast to the Five Star movement's narrative, Rousseau was not a proponent of direct democracy, majority votes, or giving individuals the power to decide over particular law-making. In addition, the figure of authority prevalent in Emile demonstrates his belief in a controlling force, which actively but covertly manipulates the environment of its subject. By doing so, reality becomes an illusion of freedom and individual autonomy. The proprietary Rousseau platform, just like any other online space, is not free or natural. It is a purposefully built, curated zone which in this case is politically laden and intermingled with private enterprise. In this sense it becomes an anti-modern public sphere, with the inherent potential to be used as a powerful tool of both preventive as well as repressive social control.

On the surface, the Five Star Movement's narrative is much in line with a utopian, deterministic view on the internet as a tool for civic emancipation. Though this is to some extent in line with Manuel Castell's theory of the networked social movement, he also observes that no matter how well-intentioned a social movement may be, its ideals will still be steered by institutional order and the political drivers in place. He considers this inevitable and to some extent hindering to meaningful political change, yet at the same time appreciates the silver lining of setting powerful examples in political practices. Specifically for Italian politics, he felt that the Five Star Movement may prompt a regeneration of the political institutions in Italy (Castells, 2012/2015, p. 283). This is also how it is perceived by persons with the movement's stakeholder groups (Federici et al., 2015, p. 288). Deseriis (2016b) notes that the party is indeed unique in its frequent and regular consultation of its members for decision-making. In other words, the legacy would be 'the cultural change it has produced through its action' (p. 315). Altogether, the denotational link between the platform and the eighteenth-century theorist may be entirely well-intentioned in its progressive ideology, and simply uncritical or naïve in its use of Rousseau as its namesake.

Despite its many critics, the utopian ideals remain tempting. A network of hope may ultimately prove to be the people's desire, setting doubts aside concerning the actuality of its promises. As to the influence of technology in itself, it remains important to appreciate its potential as a non-deterministic element within a particular context. A more constructivist stance appreciates the drivers of the people behind the political tool and factors of society at large. For those reasons, it is imperative that society continues to be mindful of political promises which sound too good to be true. Indeed, Rousseau himself - in spite of all ambiguities - regarded the government as deeply suspicious. In regards to the Five Star Movement, Castells commented specifically on the party's ideology and its actual realisation of participatory democracy: 'the jury is still out' (2012/ 2015, p. 282). 


\section{References}

Agamben, G. (2003). Iustitium. Stato di Eccezione. Turin: Bollati Boringhieri.

Agnew, J., \& Shin, M. (2017). Spatializing populism: Taking politics to the people in Italy. Annals of the American Association of Geographers, 107(4), 915-933.

Bartlett, J. (2018a). The new age of digital populism. New Statesman, 147(5410), 15-16.

Bartlett, J. (2018b). The people vs tech: How the internet is killing democracy (and how we save it). London: Ebury Press.

Bauman, Z. (2003). La Solitudine del Cittadino Globale. Milan: Feltrinelli.

Berlin, I. (2002). Freedom and its betryal: Six enemies of human liberty. H. Hardy (Ed.) Princeton: Princeton UP.

Casaleggio, D. (2017). Participate. Don't delegate. New Perspectives Quarterly, 34(2), 14-16.

Casaleggio, D. (2018). A top leader of Italy's Five Star Movement: Why we won. New Perspectives Quarterly, 35(3), 39-40.

Casaleggio, G., \& Grillo, B. (2011). Siamo in guerra. Chiare Lettere: Milano.

Castells, M. (2012/2015). Networks of outrage and hope: Social movements in the internet age. Cambridge: Polity Press.

Cohen, S. (1985). Visions of social control. Piscataway, NJ: Transation.

Deseriis, M. (2016a). A preliminary analysis of the political values embedded in Rousseau, the decision-making platform of the Five Star Movement (Part I). Retrieved from https:// scalingdemocracy.net/2016/09/27/a-preliminary-analysis-of-the-political-values-embedded-inrousseau-the-decision-making-and-organizational-platform-of-the-five-star-movement-part-i.

Deseriis, M. (2016b). A preliminary analysis of the political values embedded in Rousseau, the decision-making platform of the Five Star Movement (Part II). Retrieved from https:// scalingdemocracy.net/2016/10/04/a-preliminary-analysis-of-the-political-values-embedded-inrousseau-the-decision-making-platform-of-the-five-star-movement-part-ii/.

Deseriis, M. (2017). Technopopulism: The emergence of a discursive formation. TripleC, 15(2), 441458.

Deseriis, M. (2018). On the decline of participation and voter turnout in Rousseau. Scalable Democracy. Retrieved from https://scalingdemocracy.net/2018/01/17/on-the-decline-of-onlineparticipation-in-rousseau.

Federici, T., Braccini, A. M., \& Saebø, ø. (2015). 'Gentlemen, all aboard!' ICT and party politics: Reflections from a mass-eParticipation experience. Government Information Quarterly, 32(3), 287-298.

Foucault, M. (1976). Difendere la Società. Florence: Ponte alle Grazie.

Gray, P. (2015). Rousseau's errors: They persist today in educational theory. Issues in Early Education, 3, 23-28.

Habermas, J. (1962/1974). Storia e Critica dell'Opinione Pubblica. Laterza: Bari.

Hill, C. (2017). How can liberal democracies defend themselves against tyranny? Perspectives on Political Science, 46(4), 243-246.

Horkheimer, M. (1947). The eclipse of reason. Oxford: Oxford UP.

Horowitz, J. (2018, February 28). The mystery man who runs Italy's 'Five Star' from the shadows. The New York Times. Retrieved from https:/www.nytimes.com/2018/02/28/world/europe/italyelection-davide-casaleggio-five-star.html.

Kelly, C. (2018). Sovereign versus government: Rousseau's republicanism. Acta Politologica, 10(2), $15-32$.

Kelly, G. A. (2006). A general overview. In P. Riley (Ed.), The Cambridge companion to Rousseau (pp. 856). Cambridge: Cambridge UP.

Loucaides, D. (2019, February 14). What happens when techno-utopians actually run a country. Wired. Retrieved from https://www.wired.com/story/italy-five-star-movement-techno-utopians/.

Lyon, D. (2007). La Società della Sorveglianza. Milan: II Saggiatore.

Lyon, D. (2015). Surveillance after Snowden. London: Polity Press.

Lyon, D. (2018). The culture of surveillance. London: Polity Press.

Melossi, D. (2003). Stato, Controllo Sociale e Devianza. Milan: Bruno Mondadori. 
Natale, S., \& Ballatore, A. (2014). The web will kill them all: New media, digital utopia, and political struggle in the Italian 5-Star Movement. Media, Culture \& Society, 36(1), 105-121.

Negri, A., \& Hardt, M. (2000). Empire. Harvard, MA: Harvard UP.

Politi, J. (2017, September 17). Five Star Movement: the unanswered questions about Italy's populist party. Financial Times. Retrieved from https://www.ft.com/content/546be098-989f-11e7-a652cde3f882dd7b.

Potts, D. (2015, June 28). Were Rousseau's Children Victims of his Moral Theory? Policy of Truth. Retrieved from https://irfankhawajaphilosopher.com.

Reisert, J. (2003). Jean-Jacques Rousseau: A friend of virtue. Ithaca/London: Cornell UP.

Rousseau, J. (1762/1979). Emile, or on education. (A. Bloom, Trans.). USA: Basic Books.

Rousseau, J. (1762/1994). Discourse on political economy and the social contract. (C. Betts, Trans.). Oxford: Oxford UP.

Shklar, J. (1964). 'Rousseau's images of authority. The American Political Science Review, 58(4), 919932.

Simon, J. (2012). Diverting water in Rousseau: Technology, the sublime, and the quotidian. The Eighteenth Century, 53(1), 73-97.

Szkudlarek, T. (2017). On the politics of educational theory: Rhetoric, theoretical ambiguity, and the construction of society. London: Routledge.

Trifonas, P. (2006). Derrida and Rousseau: Deconstructing the ethics of a pedagogy of the supplement. Review of Education, Pedagogy, and Cultural Studies, 22(3), 243-265.

Trinchi, O. (2019, May 3). The truth, I beseech you, on the 5 Star Movement. Eastwest. Retrieved from https://eastwest.eu/en/italy-calls-on-europe/interview-nicola-biondo-five-star-movement.

Turner, E. (2013). The 5 Star Movement and its discontents: A tale of blogging, comedy, electoral success and tensions. Interface: A Journal for and About Social Movements, 5(2), 178-212.

Weber, M. (1971). Il Lavoro Intellettuale come Professione. Turin: Einaudi.

Williams, D. L. (2005). Modern theorist of tyranny? Lessons from Rousseau's system of checks and balances. Polity, 37(4), 443-446. 